Meta

Journal des traducteurs

Translators' Journal

\title{
Conference Interpreting: Practice and Teaching in South Brazil
}

\section{Hedy Lorraine Hofmann}

Volume 35, numéro 3, septembre 1990

La traduction dans le monde hispanolusophone

URI : https://id.erudit.org/iderudit/003075ar

DOI : https://doi.org/10.7202/003075ar

Aller au sommaire du numéro

Éditeur(s)

Les Presses de l'Université de Montréal

ISSN

0026-0452 (imprimé)

1492-1421 (numérique)

Découvrir la revue

Citer cet article

Hofmann, H. L. (1990). Conference Interpreting: Practice and Teaching in South Brazil. Meta, 35(3), 652-655. https://doi.org/10.7202/003075ar d'utilisation que vous pouvez consulter en ligne.

https://apropos.erudit.org/fr/usagers/politique-dutilisation/ 


\title{
CONFERENCE INTERPRETING: PRACTICE AND TEACHING IN SOUTH BRAZIL
}

\author{
Hedy LoRRAINe HoFMANN \\ Universidade Federal do Rio Grande do Sul, Brazil
}

This, I believe, is almost the typical story of how one becomes a conference interpreter in an area where there were none before. It is also a description of an Interpreters Course in a vast region where a single language is used.

In 1969, I had just taken a degree as language teacher, and was working for a travel agency, while waiting for a DAAD fellowship to Heidelberg, when an ad appeared in the newspaper requesting an English-language interpreter to work at the Federal University of Rio Grande do Sul, in a Water Resources Project sponsored by UNESCO/UNDP. That was the beginning of a career as conference interpreter.

When I began, I had never even seen conference interpreting done, although I had some previous experience as an escort interpreter at the Universidade, when it was held in 1963, in Porto Alegre, south Brazil. Then I had the opportunity of studying French Language and Culture at the Sorbonne. The idea of becoming a translator or interpreter had crossed my mind, since I spoke several languages, but I gave it up early on as an impossible dream, requiring long and unaffordable studies in Europe. I was all set to become a secretary, when I returned from Germany, because I did not enjoy teaching.

Yet, here I was, working as an interpreter, without the slightest idea of techniques, theory or history. With hindsight, it was a serious disadvantage to have had electronic equipment available from the word go. I now realize that it would have been far better to begin by doing consecutive interpreting. But I was a natural interpreter, at a time and place when it began to occur to people in this region that it was preferable to hear lectures immediately through an interpreter, than to listen in open-mouthed wonder and have it all explained later, or to interrupt the lecturer every once in a while, disturbing those who understood the foreign language, and interrupting the speaker's train of thought.

It should be added that in the very beginning, many people did not really understand what interpreting meant. Some actually thought, when one stated "Interpreter" as profession, that it meant one was a singer. Others thought that the equipment worked on its own, without human participation (machine translation!). In fact, one medical doctor wanted to buy a receiver because he was going on a trip to Europe and did not know any language but Portuguese. Yet others were heard to grumble because interpreters were a few words behind the lecturer ("They charge such high fees and should really be able to at least keep up!"). Then, there were the self-appointed language experts, who would sit there trying to listen to both lecturer and interpreter, in an attempt to catch the latter out, by checking on single words. Fortunately they soon tired!

For the first few years I worked completely alone at the Institute of Hydraulic Research, as I now know, against all rules of good sense, up to four hours a day in the booth, alone. Then a man who organized conventions and seminars heard about me, and began to call me for events outside the Project. During the course of this work, I met two 
colleagues and, together, our work load slowly grew. It seemed as though the availability of equipment and people to work it had caused a market to develop.

Up to this point, I still did not know what went on in the field of interpreting anywhere else, in Brazil or the rest of the world. Both colleagues had taken an Interpreters course which no longer exists, at the Pontifical Catholic University, but they certainly knew no more than I did.

Although I participated in 1975 in a group of interpreters from Rio and Germany, as a local supernumerary, at a meeting on Metropolitan Areas, my first real contact with other interpreters from Sào Paulo was at a large Cardiology Convention, in 1976.

As I worked with them, I began to learn more about the formal, organized aspects of the profession. About that time I was invited to teach at a newly created course of translating and interpreting, at the Federal University of Rio Grande do Sul, where I was already working officially as a translator.

Teaching meant that first I was obliged to think about what I had been doing, and to look around for materials to be used in class.

Not really knowing what to do, I began by talking about my personal experiences, and this forced me to organize the preceding 7 years in my mind, trying to find my own theories to impart something approaching a methodology. Then a teacher of translation lent me books by Herbert, Seleskovitch and Rozan. In reading them I found that someone had already put into words what I had noticed through the years, and that instinctively I had been coming to appropriate conclusions and following certain classical guidelines.

Once contact had been established with colleagues from other parts of Brazil, I heard a bit about the history of interpreting in this country: about the group of Edith van der Beuque working in Rio de Janeiro since after World War II, and about the group of interpreters that began their activities in Sào Paulo, in 1954, on the occasion of the City's Fourth Centennial, and later organized the Professional Association of Conference Interpreters (APIC). I worked with this group occasionally, from 1976 onwards, and whenever I did so, I considered it a seminar, and an occasion for self-improvement, by trying to measure up to their standards.

I was also able to make short visits to interpreter courses in Europe (Heidelberg and E.S.I.T.) to observe their teaching methods.

Most of the work outside the Water Resources Project, by then, was in the fields of Medicine, Engineering and Environmental Sciences. In south Brazil much of the interpreting is done in technical and scientific fields. Only recently have Politics, Economics and the Law become increasingly important. People have come to consider interpreting an essential part of normal proceedings, when a foreign expert is present, as a lecturer or as a listener.

In fact, the latter is one of the pitfalls in teaching (and learning) interpreting. Obviously, almost everyone here has Brazilian Portuguese as their A language. But a lot of the work is done for those foreign participants. It is not simply a matter of short translations of a few questions. Whole speeches and debates are involved. Organizers think it most impolite to just leave a visitor sitting there without providing him/her with a means of understanding. They also have a habit of organizing panels and round tables.

Having gathered materials to teach interpreting at such a great distance from all centers where it is practiced on a large scale, the problem of a single class for Theory and Techniques, with students from all five modern languages (English, French, German, Italian and Spanish) taught for a Bachelor's degree at our University, had to be faced. The variety of languages, besides the fact that many of the students were just beginning to learn them, prevented going very far with practical work and exercises, except 
for demonstration purposes. Since they are mostly beginners, and a few of them have a sufficiently agile and extensive vocabulary to think of working as interpreters for years to come, not to mention the lack of previous vocational tests, it can easily be perceived that out of 26 students in a class, at most 4 or 5 may attempt to become proper conference interpreters in future.

Besides insufficient expertise in languages, the students usually have a poor knowledge of History, Geography, Literature, World Events and General Culture. The high school system was reformed years ago, removing many of the basic subjects of Humanities, which originally provided an all-round education. Succeeding classes have proved that these subjects are sorely lacking.

Two factors therefore, lack of linguistic knowledge and general culture, have been the main stumbling blocks affecting even translation courses, especially in languages other than English, at our University. Another serious problem is that one has to be prepared to learn a subject in a hurry, and try to understand technical matters, so that it will all make sense to the listeners. It is also necessary to know where to find the information, since very few conference organizers, despite repeated requests, actually supply material on the subject beforehand, much less copies of written speeches.

In the Theory course, besides types of interpreting, equipment, history and exercises in note-taking, memory development, public speaking and gathering information, an attempt is made to teach them about the main international organizations. The terrain is thus prepared for the specific language sections to deal with interpreting proper, when the students have acquired sufficient linguistic knowledge. Most students who wish to become interpreters first study translation, and then take the remaining courses over another two-and-a-half years, 2 years of interpreting, mainly in a laboratory, and one year of practical work, if this can be arranged, beginning during the second half of the second year.

Very few students actually know what is involved when they decide that they want to become interpreters. Therefore, while we teach them Conference Interpreting theory, we try to point out that there is also escort work which does not necessarily require the same skills and level of information in language use.

Most potential interpreters are found in the English-language section. They have greater opportunities for travelling abroad. Many of the best students have been on American Field Service or Youth for Understanding scholarships in the USA. German is the most difficult language, and should really be handled much more intensively during the first few years of the language course, despite the fact that a large proportion of the population of Rio Grande do Sul is of German extraction. In fact, if as many mistakenly believe, simple knowledge of the language were sufficient, our state ought to be full of German interpreters and translators. Yet they are very rare. These students are encouraged to spend a time in Germany before taking up the study of interpreting, so as to acquire the essential speed and general culture which cannot really be learned only from books, and only can be helped up to a certain point by passive viewing of videos.

A curiosity regarding Rio Grande do Sul is that there is little need here for Spanishlanguage interpreters. The state borders with Uruguay and Argentina, and the population understands and can make itself understood in Spanish (or Spanoguese or Portunhol as some language mixes are informally known). But, lately, Latin American conferences have taken place which have required interpreters from and into Spanish due to the presence of people from other areas of Brazil, and no local interpreter has Spanish as an A language.

Another aspect is the problem that local graduates, unless they come from an international family, tend to have Portuguese as an A language and only one B or C language. That makes it hard on clients attempting to set up a team for a congress, if, say, 3 lecturers 
are English-speaking and only one other is going to speak for a short while in French or German. The Sào Paulo and Rio de Janeiro interpreters apparently come from multilingual, international families, and that is really essential.

But the market for interpreting has grown apace, even during this time of economic recession. Quite a few people now live from translating and/or interpreting, although as yet few people, at least in the states of Rio Grande do Sul and Santa Catarina, can live exclusively from one of these. 